DOI: $10.37555 / 2707-3114.17 .2021 .248335$ УДК 581.6(477)
(C) 2021 Gritsenko. This article is distributed under the terms of CC Attribution-ShareAlike 4.0 International described at https://creativecommons.org/licenses/by-sa/4.0

Вікторія В. Гриценко

Національний ботанічний сад імені М. М. Гришка НАН України, м. Київ, e-mail: gritsenkoviktoria@ gmail.com; ORCID ID 0000-0002-1783-6977

\title{
Реферат.
}

Mema. Скласти та проаналізувати анотований перелік автохтонних вітаміноносних видів рослин Київського плато, які за етноботанічними традиціями часто використовує населення цього регіону. Методи. Дослідження проводились у 2002-2021 pp. у природних фітоценозах Київського плато та штучних фітоценозах Національного ботанічного саду імені М. М. Гришка НАН України (НБС). Методи досліджень - польові та камеральні. Для 3'ясування, які саме автохтонні вітаміноносні види рослин використовує населення регіону найбільш часто, проводились опитування десятків місцевих жителів. Латинські назви рослин наведені відповідно до загальноприйнятої таксономії (Mosyakin \& Fedoronchuk, 1999). Для біоморфологічного аналізу використана лінійна система (Golubev, 1972). Для еколого-ценотичного аналізу застосували класифікаційну схему флороценотипів (Kamelin, 1973). Результати. Наведено анотований перелік автохтонних вітаміноносних видів рослин Київського плато, які часто використовує населення регіону. Проаналізовані спектр родин, біоморфологічний і еколого-ценотичний спектри та пріоритетність використання певних частин рослин. Висновки. В анотованому переліку охарактеризовані 43 види рослин, які належать до 36 родів та 21 родини. У спектрі родин найбільшу частку займають види Rosaceae (26\%). У біоморфологічному спектрі переважають трав'янисті рослини (61\%), а саме, трав'янисті полікарпіки (49\%). В еколого-ценотичному спектрі найбільшими є частки видів лісового (42\%) та лучного (33\%) флороценотипів. Для практичного застосування населення регіону найчастіше збирає надземні частини рослин, зокрема, надземні пагони (46\%) або надземні пагони і плоди (33\%). Усі наведені в анотованому переліку види рослин представлені ex situ у НБС. Більш ніж половина з них $(65,1 \%)$ експонуються на ботаніко-географічній ділянці «Степи України» НБС.

Ключові слова: етноботанічні традиції, вітаміни, природна флора, Національний ботанічний сад. 


\title{
Autochthonous vitamin-bearing plants of the Kiev Plateau \\ Victoria V. Gritsenko \\ M. M. Gryshko National Botanical Garden NAS of Ukraine, Kyiv, Ukraine, e-mail: gritsenkoviktoria@gmail.com; ORCID ID 0000-0002-1783-6977
}

\begin{abstract}
.
Aim. To compile and analyze an annotated list of autochthonous vitaminbearing plant species of the Kiev Plateau, which according to ethnobotanical traditions are often used by the population of this region. Methods. The research was carried out in 2002-2021 in natural phytocoenoses of the Kyiv Plateau and artificial phytocoenoses of M. M. Gryshko National Botanical Garden, National Academy of Sciences of Ukraine (NBG). Research methods are field and cameral. Dozens of locals were surveyed to find out which autochthonous vitamin-bearing plant species are most commonly used by the region's population. Latin names of plants are given according to the generally accepted taxonomy (Mosyakin \& Fedoronchuk, 1999). A linear system (Golubev, 1972) was used for biomorphological analysis. The classification scheme of florocoenotypes (Kamelin, 1973) was used for ecologocoenotic analysis. Results. An annotated list of autochthonous vitamin-bearing plant species of the Kyiv Plateau, which is frequently used by the population of the region, is given. The spectrum of families, biomorphological and ecologo-coenotic spectra, and priority of use of certain parts of plants are analyzed. Conclusions. The annotated list describes 43 species of plants belonging to 36 genera and 21 families. Rosaceae (26\%) has the largest share in the spectrum of families. The biomorphological spectrum is dominated by herbaceous plants $(61 \%)$, namely, herbaceous polycarpics $(49 \%)$. In the ecologo-cenotic spectrum, the largest share is occupied by species of forest (42\%) and meadow (33\%) florocoenotypes. For practical use, the population of the region most often collects aboveground parts of plants, in particular, aboveground shoots (46\%) or aboveground shoots and fruits (33\%). All plant species listed in the annotated list are presented ex situ in the NBG. More than half of them (65.1\%) are exhibited on the botanical-geographical plot "Steppes of Ukraine" of the NBG.
\end{abstract}

Key words: ethnobotanical traditions, vitamins, natural flora, National Botanical Garden.

Bступ/Introduction. Світова флора подарувала людству значну кількість рослин, які широко використовуються у різних етноботанічних сферах. Вся флора складається із флори природної (спонтанної) та культурної (похідної). Джерелом природних вітамінів можуть слугувати представники як природної, так і культурної флори (Zhohlo et al., 1992; Nechitaylo et al., 2005). Природна флора певних регіонів включає автохтонні та адвентивні види. Автохтонні вітаміноносні рослини природної флори застосовувались нашими пращурами відповідно до регіональних традицій ще з давніх часів (Bosse, 1943), а зібранні ними знання та секрети передавались із вуст в уста від старшого покоління до наступного. Вітаміноносними вважають рослини, які містять значну кількість 
вітамінів або провітамінів (Gusev et al., 2017). Вітаміни — це необхідні для нормальної життєдіяльності низькомолекулярні органічні речовини різноманітної хімічної природи, синтез яких в організмі відсутній або обмежений (Aleksandrova et al., 2015). За участю вітамінів забезпечується функціонування організму та його спротив шкідливим чинникам довкілля. Вітаміноносними, у широкому розумінні, вважається значна кількість рослин, що зазвичай мають і різні лікарські властивості. Певні види цих рослин можуть використовуватись як харчові, ароматичні, декоративні, медоносні, фарбувальні тощо. Нині кожна людина має вибір між вживанням природних вітамінів, наявних у харчових продуктах, зокрема у рослинах, або їх хімічно синтезованими аналогами - фармацевтичними препаратами. Висока ефективність вітаміноносних рослин обумовлена збалансованим природним співвідношенням біологічно активних речовин, які нормалізують обмінні процеси в організмі. Отже, автохтонні рослини природної флори є стародавнім, традиційним джерелом вітамінів. Як свідчать літературні відомості останніх п’яти років (Gusev et al., 2017; Rahimi-Madiseh et al., 2017; Santos et al., 2017; Pehlivan et al., 2018; Taşc1 et al., 2019; Couto et al., 2020; Dhouibi et al., 2020; Kajszczak et al., 2020; Mendel et al., 2020), різнопланові дослідження вітаміноносних рослин залишаються актуальним питанням сучасності. Вітаміноносні рослини широко експонуються ex situ у ботанічних установах.

Мета/Aim. Скласти та проаналізувати анотований перелік автохтонних вітаміноносних видів рослин Київського плато, які за етноботанічними традиціями часто використовує населення цього регіону.

Матеріали i методи/Materials and Methodology. Дослідження проводились у 2002-2021 pp. у природних фітоценозах Київського плато та штучних фітоценозах Національного ботанічного саду імені М. М. Гришка НАН України (НБС). Методи досліджень — польові (флористичні маршрутноекспедиційні й стаціонарні) та камеральні (визначення видів, обробка даних).

Для з'ясування, які саме автохтонні вітаміноносні види рослин використовує населення регіону за етноботанічними традиціями найбільш часто, проводились опитування десятків місцевих жителів, зокрема, сільських старожилів. Спирались також на власний досвід (Gritsenko, 2007; 2021). Складено анотований перелік автохтонних вітаміноносних видів рослин Київського плато, який подано за романським алфавітом. Види визначали за визначником вищих рослин України (Dobrochaeva et al., 1999). Латинські назви рослин наведені відповідно до загальноприйнятої таксономії (Mosyakin \& Fedoronchuk, 1999). Для біоморфологічного аналізу основних життєвих форм використана лінійна система (Golubev, 1972). Для еколого-ценотичного аналізу застосували класифікаційну схему флороценотипів (Kamelin, 1973). Представлені на діаграмах дані у \%, автоматично округлені до цілих чисел.

Види, які експонуються ex situ в штучно створеному фітоценозі на ботаніко-географічній ділянці «Степи України» НБС, у переліку позначені *. Всі фотографії виконані автором на ботаніко-географічній ділянці «Степи України» НБС камерою Canon Power Shot SD 4000 IS Digital ELPH. 
Результати та обговорення/Results and Discussion. Київське плато орографічно являє собою підняття на Правобережжі р. Дніпро у північній частині Лісостепової зони, яке в адміністративному плані займає центральні райони Київської області та північну частину Черкаської (Gritsenko, 2007). Нижче наводимо анотований перелік автохтонних вітаміноносних видів рослин Київського плато, складений відповідно до поставленої мети. У переліку для кожного виду вказані наступні відомості. Латинська назва, у дужках — родина, пріоритетна українська назва або декілька назв. Основна життєва форма дерево, кущ, кущик, трав'янистий полікарпік, трав'янистий монокарпік. Флороценотип - лісовий, лучний, степовий, псамофільний, синантропний, у дужках — різноманіття природних місць зростання у регіоні досліджень. Далі вказані певні частини рослини, які зазвичай використовують - надземні пагони (повністю або частково, зокрема, бруньки, листки, сік, кора, бутони, квітки, суцвіття, верхівки квітучих пагонів), плоди (виділяємо в окрему групу, як органи захисту і розповсюдження насіння, що формуються на надземних пагонах), підземні пагони (цибулини, кореневі бульби, кореневища) та особливості їх використання, які можна застосовувати лише за умови консультації з лікарем та відсутності індивідуальних протипоказань.

\section{Анотований перелік}

автохтонних вітаміноносних видів рослин Київського плато, які за етноботанічними традиціяи часто використовус населення цього регіону

Achillea millefolium L. * (Asteraceae Juss.), деревій звичайний (рис. 1a). Трав'янистий полікарпік. Лучний (на луках, трав'янистих схилах, узліссях, лісових галявинах, серед чагарників). Рослина відома 3 глибокої давнини, переважно як лікарська. У якості вітаміноносного засобу, для поліпшення апетиту та обміну речовин використовують верхівки квітучих пагонів. Їх сушать для чаю або вживають свіжий сік з медом.

Achillea setacea Waldst. \& Kit. * (Asteraceae), деревій щетинистий. Трав'янистий полікарпік. Степовий (у лучних степах, на степових схилах, сухих луках, узліссях, лісових галявинах). Верхівки квітучих пагонів застосовують, як у A. millefolium.

Agrimonia eupatoria L. (Rosaceae Juss.), парило звичайне. Трав'янистий полікарпік. Степовий (у лучних степах, на степових схилах, пагорбах, сухих луках, узліссях, лісових галявинах і серед чагарників). Заготовляють надземні пагони під час цвітіння, додають до вітамінних чаїв, відварів. Настої цієї рослини мають антиоксидантну, протизапальну та знеболювальну дію (Santos et al., 2017). Антиоксиданти сповільнюють чи припиняють окислення та допомагають запобігати пошкодженню клітин організму.

Alliaria petiolata (M. Bieb.) Cavara \& Grande (Brassicaceae Burnett.), часникова трава, кінський часник черешковий. Трав'янистий монокарпік. Лісовий (у лісах, на узліссях, серед чагарників). Рослина має специфічний 
часниковий запах. Надземні пагони збирають у період цвітіння. Вживають як вітамінну приправу замість часнику у свіжому стані, для зберігання сушать.

Allium oleraceum L. * (Alliaceae J. Agardh), цибуля овочева, цибуля дика, часник польовий (рис. 1b). Трав'янистий полікарпік. Степовий (у лучних степах, на степових і трав'янистих схилах, сухих луках, узліссях, лісових галявинах, серед чагарників). Вітаміноносними $є$ як надземні пагони, так i підземні - цибулини. Їх вживають сирими або при приготуванні різних страв.

Allium scorodoprasum L. * (Alliaceae), цибуля часникова, часник іспанський (рис. 1c). Трав'янистий полікарпік. Лучний (на луках, трав'янистих схилах, узліссях, лісових галявинах, серед чагарників). Іноді використовують молоді надземні пагони, однак, частіше підземні пагони - цибулини, які на смак подібні до часнику. Їх вживають сирими, додаючи до салатів, або при приготуванні перших і других страв. Цибулини мають лікарські властивості, покращують травлення. Надземні та підземні пагони рослини характеризуються антиоксидантною активністю (Taşcı et al., 2019).
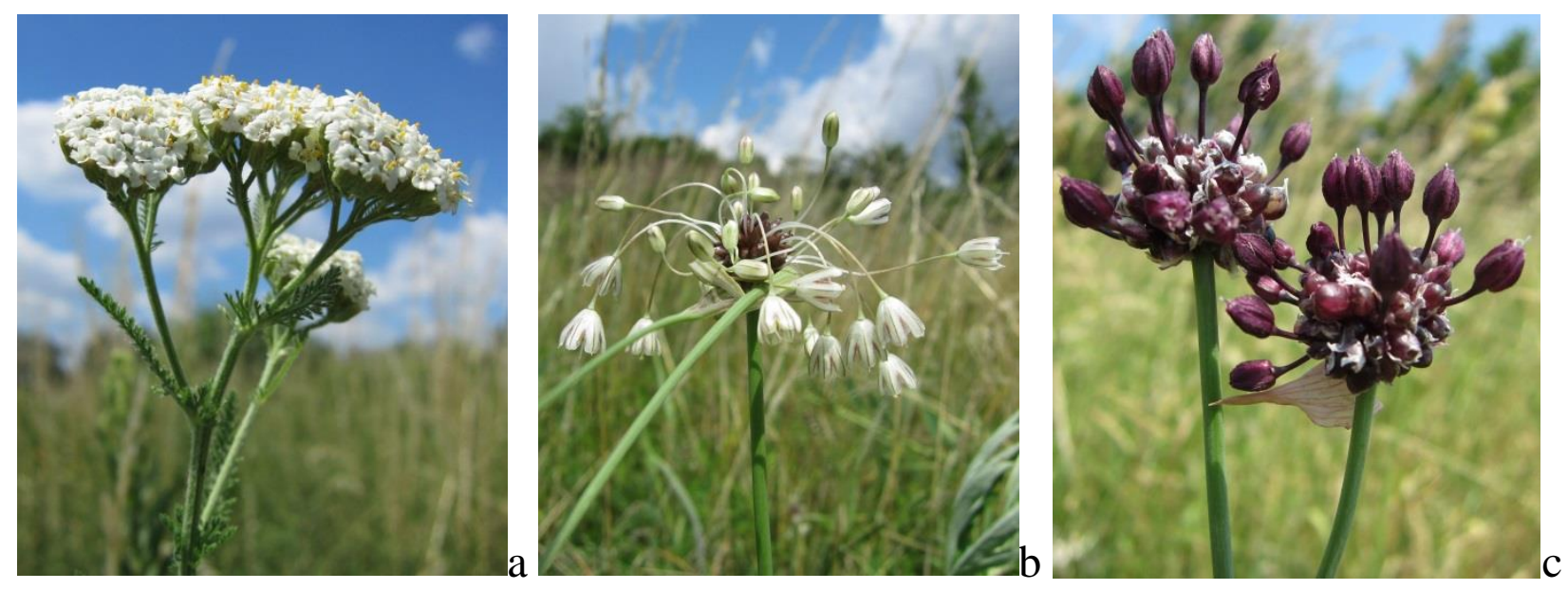

Рисунок 1. a - Achillea millefolium L.; b - Allium oleraceum L.;

c - Allium scorodoprasum L. (Фото В. В. Гриценко)

Figure 1. a - Achillea millefolium L.; b - Allium oleraceum L.; c-Allium scorodoprasum L. (Photo by V. V. Gritsenko)

Berberis vulgaris L. * (Berberidaceae Juss.), барбарис звичайний (рис. 2a). Кущ. Лісовий (у лісах, на узліссях, галявинах, серед чагарників, на трав'янистих схилах). Застосовується як вітаміноносна рослина, а також у традиційній і народній медицині, гомеопатії (Rahimi-Madiseh et al., 2017). Молоді листки можна споживати свіжими, додаючи у салати, та використовувати замість щавлю у перших стравах. У регіоні досліджень вживають переважно плоди у свіжому або висушеному стані. Цілі плоди використовують для приготування страв 3 рисом та компотів. Висушені та перемелені $з$ кісточками плоди додають, як приправу до перших і других страв, при приготуванні м'яса та бобових.

Betula pendula Roth * (Betulaceae S. F. Gray), береза повисла (рис. 2b). Дерево. Лісовий (у лісах та на узліссях). Рано навесні місцеві жителі традиційно 
заготовляють вітамінний березовий сік, який позитивно впливає на обмін речовин. Його вживають свіжим, консервують, готують березовий квас. Також збирають бруньки та молоді листки, які додають до цілющих вітамінних чаїв.

Bidens tripartita L. (Asteraceae), череда трироздільна. Трав'янистий монокарпік. Лучний (на вологих луках та серед чагарників). Збирають верхні частини надземних пагонів до цвітіння та сушать для зберігання. Додають до вітамінних чаїв, вживають для поліпшення крові, обміну речовин, травлення та роботи шлунково-кишкового тракту (Mendel et al., 2020). В Україні трава череди застосовується в офіційній і народній медицині. У череді місцеві жителі традиційно купають немовлят для запобігання шкірних висипів та діатезу.

Chenopodium album L. * (Chenopodiaceae Vent.), лобода біла. Трав'янистий полікарпік. Синантропний (на трав'янистих схилах, поблизу садиб та осель). Молоді листки та надземні пагони — вітаміноносні, їстівні у сирому та вареному вигляді. Рослина має лікарські властивості: антисептичні, знеболювальні, протизапальні.

Corylus avellana L. * (Betulaceae), ліщина звичайна (рис. 2c). Кущ. Лісовий (у лісах, на узліссях та серед чагарників). Зі стародавніх часів плоди ліщини горіхи, вважаються цінним харчовим продуктом. Вони містять значну кількість жирів, білків, мають високу калорійність і $є$ джерелом вітамінів. Вживання горіхів ліщини активує роботу мозку, зміцнює судини, пам'ять та в цілому позитивно впливає на організм людини.
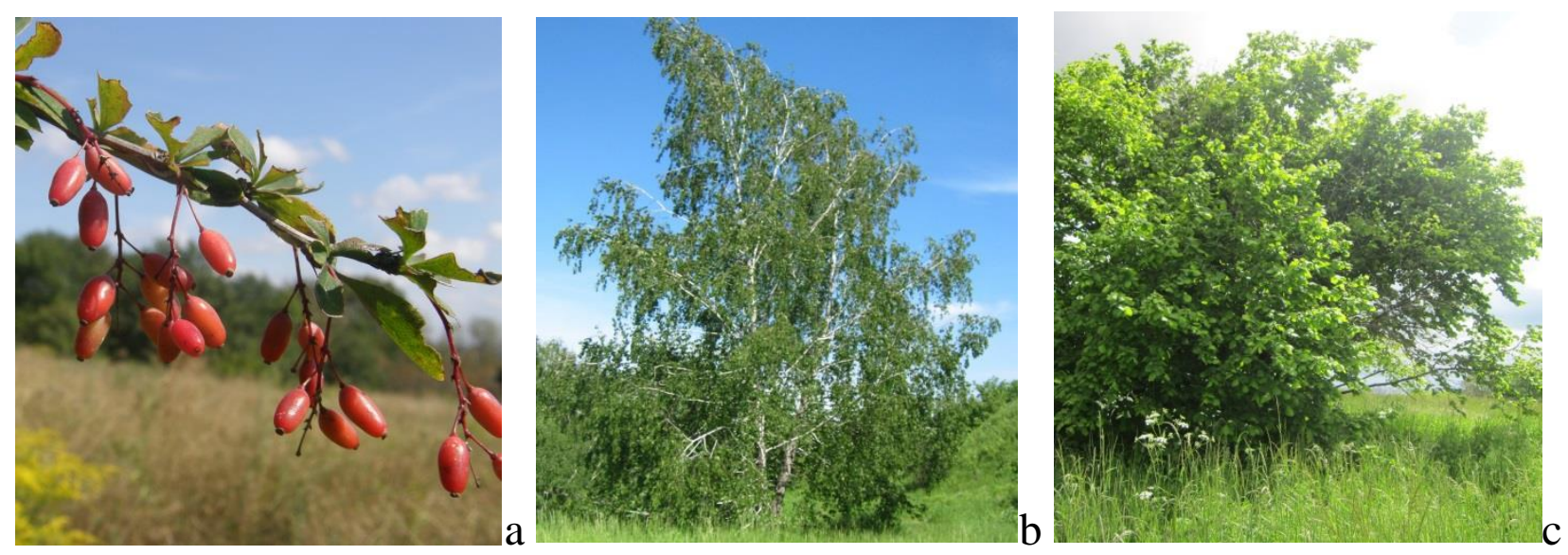

Рисунок 2. a - Berberis vulgaris L.; b - Betula pendula Roth;

c - Corylus avellana L. (Фото B. В. Гриценко)

Figure 2. a - Berberis vulgaris L.; b - Betula pendula Roth;

$\mathrm{c}$ - Corylus avellana L. (Photo by V. V. Gritsenko)

Crataegus curvisepala Limdm. * (Rosaceae), глід кривочашечковий (рис. 3a). Дерево (або кущ). Лісовий (на узліссях, галявинах, схилах, серед чагарників). Плоди $з$ однією кісточкою. Застосовують квітучі пагони та плоди. Їх сушать $\mathrm{i}$ додають до вітамінних чаїв і настоїв. Плоди можна вживати сирими, варити варення, компоти. Глід має лікарські властивості, нормалізує кров'яний тиск, 
сон, нервову систему. Населення регіону використовує також i iнші, менш поширені, види глоду.

Elytrigia repens * (L.) Nevski (Poaceae Barnhart), пирій повзучий. Трав'янистий полікарпік. Лучний (на луках, трав'янистих і степових схилах, узліссях, лісових галявинах, поблизу садиб та осель). Висушені підземні пагони (кореневища) використовують як вітамінний та кровоочисний засіб, для нормалізації обміну речовин, у народній медицині - для лікування запалень i порушень в організмі.

Erodium cicutarium (L.) L’Her. (Geraniaceae Juss.), грабельки звичайні. Трав'янистий монокарпік. Лучний (на сухих луках, трав'янистих схилах, узліссях, у посівах). Надземні пагони збирають під час цвітіння та сушать. Застосовують як вітамінний, протизапальний, в’яжучий, заспокійливий засіб.

Ficaria verna Huds. * (Ranunculaceae Juss.), пшінка весняна. Трав’ янистий полікарпік. Лучний (на луках, схилах, у вологих лісах, на узліссях, галявинах, серед чагарників). До початку цвітіння цього ранньовесняного ефемероїда можна вживати відварені молоді листки (надземні пагони) та кореневі бульби (підземні пагони), які містять вітаміни. Рослину застосовують у народній медицині та гомеопатії.

Fragaria vesca L. (Rosaceae), суниці лісові. Трав'янистий полікарпік. Лісовий (у лісах, на узліссях, галявинах, серед чагарників). Плоди (багатогорішки) суниці, які містять значну кількість вітамінів і антиоксидантів, споживати найбільш корисно свіжими. 3 них готують варення, компоти, кондитерські вироби, які зберігають аромат свіжих плодів. Заготовляють (сушать) листки під час цвітіння та плоди, які додають до вітамінних чаїв. Суниці - популярний дієтичний продукт, лікувальний засіб для покращення обміну речовин, роботи серцево-судинної системи, шлунково-кишкового тракту. Екстракт F. vesca є перспективним для косметологіï (Couto et al., 2020).

Fragaria viridis Duchesne * (Rosaceae), суниці зелені (рис. 3b). Трав'янистий полікарпік. Степовий (у лучних степах, на степових i трав'янистих схилах, пагорбах, узліссях, серед чагарників). Плоди на смак більш солодкі, ніж у суниць лісових. Використання - як у F. vesca.

Helichrysum arenarium (L.) Moench * (Asteraceae), цмин пісковий. Трав'янистий полікарпік. Псамофітний (на сухих луках, пагорбах, схилах, у соснових лісах). Верхівки пагонів збирають на початку цвітіння, сушать, додають до вітамінних чаїв. Використовують в офіційній та народній медицині.

Hypericum perforatum L. * (Clusiaceae Lindl.), звіробій звичайний (див. рис. 3c). Трав'янистий полікарпік. Степовий (у лучних степах, на степових i трав'янистих схилах, луках, узліссях, серед чагарників). Звіробій традиційно застосовується у медичних цілях, зокрема, для лікування дихальних шляхів, серцево-судинних, шлунково-кишкових та інших хвороб. Верхівки квітучих пагонів сушать та використовують як компонент вітамінних чаїв і настоїв.

Malus sylvestris Mill. (Rosaceae), яблуня лісова, дичка. Дерево. Лісовий (у лісах та на узліссях). Плоди дикорослої яблуні містять значно більше вітамінів, ніж культурні сорти, однак, поступаються їм за смаковими якостями та 
зовнішнім виглядом. Плоди дички невеликі (до 4 см), кислі, терпкуваті, ароматні. Їх переважно піддають перероблюванню: сушать, консервують, готують сік, варення, джеми, компоти. У сирому вигляді вживають не часто. Застосовують у народній медицині для нормалізації роботи кишковошлункового тракту.
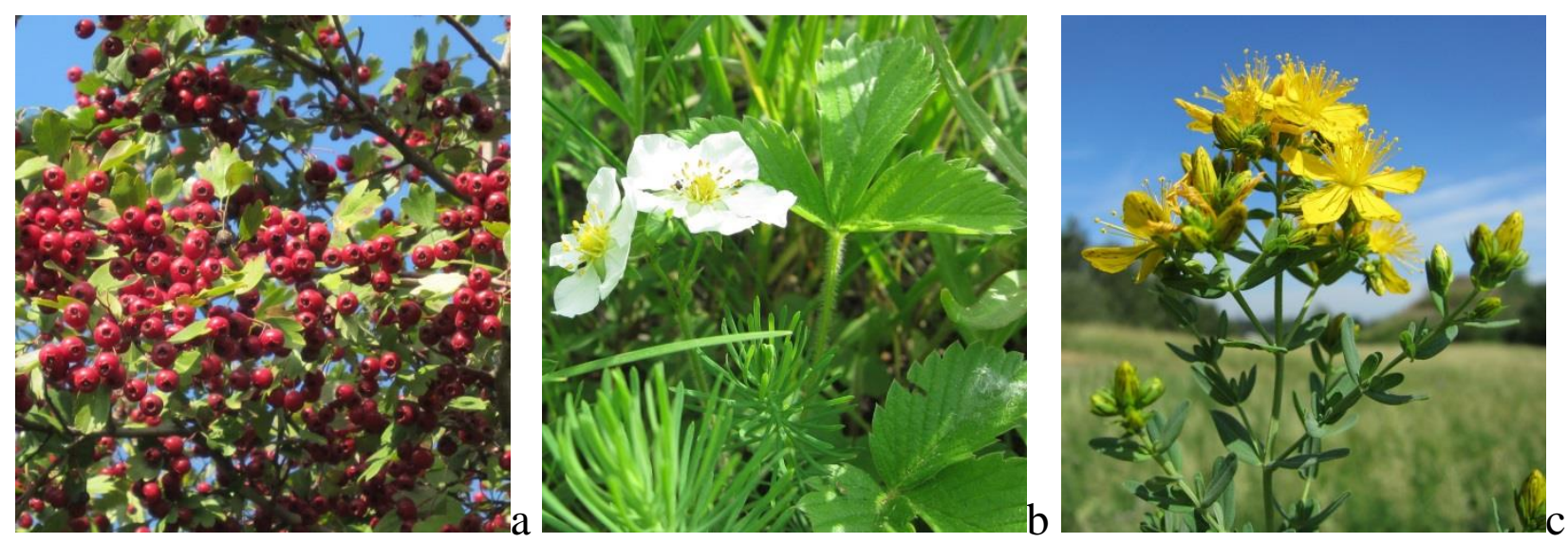

Рисунок 3. a - Crataegus curvisepala Limdm.; b - Fragaria viridis Duchesne; c-Hypericum perforatum L. (Фото В. В. Гриценко)

Figure 3. a - Crataegus curvisepala Limdm.; b - Fragaria viridis Duchesne; c - Hypericum perforatum L. (Photo by V. V. Gritsenko)

Origanum vulgare L. * (Lamiaceae Lindl.), материнка звичайна (рис. 4a). Трав'янистий полікарпік. Лучний (на сухих луках, пагорбах, трав'янистих схилах, узліссях, лісових галявинах, серед чагарників). Збирають та сушать верхівки квітучих пагонів. Материнка входить до складу вітамінних чаїв, сумішей пряних спецій. Вживають для покращення апетиту, травлення, сну. Використовують в офіційній та народній медицині. В українській етноботанічній традиції ця рослина є символом материнської турботи.

Pinus sylvestris L. (Pinaceae Lindl.), сосна звичайна. Дерево. Лісовий (у лісах, на схилах). Як вітаміноносну сировину застосовують молоді гілочки 3 бруньками (до початку розпускання) або хвоєю. Їх сушать, додають у чай. Бруньки застосовують також для лікування дихальних шляхів.

Plantago major L. * (Plantaginaceae Juss.), подорожник великий. Трав'янистий полікарпік. Лучний (на луках, трав'янистих схилах, узліссях, лісових галявинах). Свіжі листки вживають у їжу в салатах, додають до перших страв. Збирають листки до цвітіння та у період цвітіння, сушать, додають до вітамінних тонізаційних чаїв. Вживають для покращення апетиту, нормалізації роботи шлунково-кишкового тракту, підвищення гемоглобіну. Використовують в офіційній та народній медицині.

Plantago media L. * (Plantaginaceae), подорожник середній. Трав'янистий полікарпік. Степовий (у лучних степах, на степових схилах, сухих луках, узліссях). Використання - як і P. major.

Polygonum aviculare L. * (Polygonaceae Juss.), спориш звичайний, гірчак звичайний, пташина гречка. Трав'янистий монокарпік. Синантропний (на 
трав'янистих схилах, луках, вздовж стежок, поблизу садиб). Молоді надземні пагони, які містять вітаміни, додають у салати, пюре, приправи. Відвар 3 висушених рослин тонізує організм та покращує обмін речовин. Траву споришу застосовують в офіційній та народній медицині.

Prunus padus L. колишній Padus avium Mill. (Rosaceae), черемха звичайна. Дерево (або високий кущ). Лісовий (у лісах, на узліссях, серед чагарників). Плоди при повній стиглості можна вживати свіжими, сушити, консервувати, додавати до вітамінних чаїв. В офіційній медицині застосовують плоди, у народній медицині - кору, листки, квітки, плоди. Листки й квітки містять леткі фітоорганічні сполуки, що знезаражують повітря.

Prunus stepposa Kotov * (Rosaceae), терен степовий (рис. 4b). Кущ. Степовий (у лучних степах, на степових i трав'янистих схилах, узліссях, лісових галявинах, серед чагарників). Плоди вживають свіжими або переробляють. Готують сік, варення, кондитерські вироби. Висушені плоди додають у компоти, вітамінні настої, чаї. Квітки й листки також використовують для чаю.

Rosa canina L. * (Rosaceae), шипшина звичайна, шипшина собача (рис. 4c). Кущ. Лісовий (на лісових галявинах, узліссях, пагорбах, схилах, серед чагарників). Плоди шипшини - здавна відомий осередок вмісту природних вітамінів, що традиційно використовується у різних регіонах України (Rubtsova, 2007). Плоди $R$. canina проявляють високу антиоксидантну активність і їх можна вживати як природне джерело антиоксидантів (Pehlivan et al., 2018). Свіжі або сушені плоди застосовують для приготування вітамінних чаїв, відварів, настоїв. R. canina - лікарська рослина, використовується в офіційній та народній медицині, зокрема, для лікування печінки. Місцеве населення збирає також й інші види шипшин.
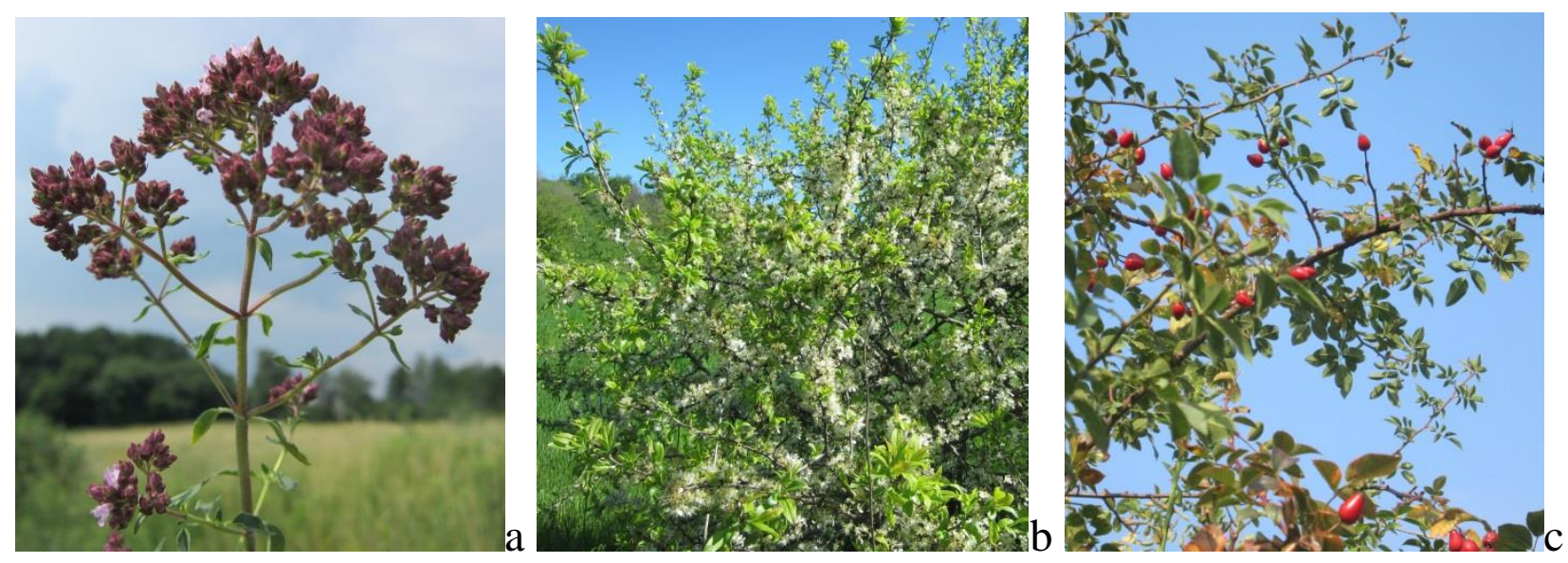

Рисунок 4. a - Origanum vulgare L.; b - Prunus stepposa Kotov;

c - Rosa canina L. (Фото В. В. Гриценко)

Figure 4. . a - Origanum vulgare L.; b - Prunus stepposa Kotov;

c - Rosa canina L. (Photo by V. V. Gritsenko) 
Rubus caesius L. (Rosaceae), ожина сиза, ожина звичайна. Кущ. Лісовий (у лісах, на узліссях, схилах, серед чагарників). Вживають свіжі, заморожені або сушені плоди. Готують варення, компоти, додають у кондитерські вироби. Для чаїв використовують також і молоді листки. Плоди ожини поліпшують роботу шлунково-кишкового тракту, сприяють очищенню крові, застосовуються у народній медицині.

Rubus idaeus L. (Rosaceae), малина звичайна. Кущ. Лісовий (у лісах, на узліссях, серед чагарників). Плоди мають високі смакові та ароматичні якості. Харчове використання - як у R. caesius. Традиційно застосовують у народній медицині для лікування застуди, грипу, зниження температури, зміцнення імунітету, в офіційній медицині - як потогінний засіб.

Rumex acetosa L. * (Polygonaceae), щавель кислий. Трав'янистий полікарпік. Лучний (на луках, трав'янистих схилах, узліссях, галявинах, серед чагарників). Листки містять щавлеву кислоту, мають кислий смак. Їх вживають свіжими для приготування салатів, соусів або відвареними (у супах, гарнірах). У народній медицині листки використовують для регулювання роботи шлунково-кишкового тракту.

Rumex confertus Willd. * (Polygonaceae), щавель кінський. Трав'янистий полікарпік. Лучний (на луках, узліссях, галявинах, серед чагарників). Рослина має лікарські властивості. Висушені підземні пагони (кореневища) застосовують для нормалізації роботи шлунково-кишкового тракту, додають при приготуванні чаїв.

Sambucus nigra L. * (Caprifoliaceae Juss.), бузина чорна (рис. 5a). Кущ. Лісовий (у лісах, на узліссях, галявинах, серед чагарників). Плоди у свіжому стані не їстівні. Стиглі плоди можна вживати після термічної обробки. 3 них готують варення, компоти, киселі, начинки для пирогів, які мають своєрідний приємний смак та аромат. Плоди бузини при кулінарному застосуванні краще смакують у суміші з різними плодами інших рослин, наприклад, суниці, яблуні, ожини, малини тощо. 3 квіток бузини готують вітамінний квас. Кору, листки, квітки та плоди використовують в офіційній та народній медицині, переважно для лікування захворювань дихальних шляхів.

Sorbus aucuparia L. (Rosaceae), горобина звичайна. Дерево (або кущ). Лісовий (у лісах у підліску, на узліссях, галявинах, серед чагарників). Плоди $\epsilon$ відомим полівітамінним засобом з високим вмістом каротину. Їх вживають у свіжому вигляді, варять варення, консервують, додають до кондитерських виробів, настоянок. Сушені плоди (можна 3 плодоніжками) додають до чаїв. При значній вітамінній недостатності сухі або свіжі плоди горобини застосовують у суміші з плодами шипшини та листям кропиви. В офіційній медицині використовують плоди, у народній медицині - ще й кору та суцвіття.

Stellaria media (L.) Vill. * (Caryophyllaceae Juss.), зірочник середній. Трав'янистий монокарпік. Лучний (на луках, трав'янистих схилах, узліссях, галявинах, серед чагарників). Молоді надземні пагони можна вживати в їжу у свіжому вигляді, додаючи до салатів і вітамінних приправ, або варити, 
використовуючи у перших стравах. Рослина широко застосовується у народній медицині, зокрема, для лікування серця, печінки, легенів.

Tanacetum vulgare L. * (Asteraceae), пижмо звичайне (рис. 5b). Трав'янистий полікарпік. Лучний (на луках, пагорбах, трав'янистих схилах, узліссях, лісових галявинах, серед чагарників). Верхівки надземних пагонів збирають на початку цвітіння та сушать. Застосовують як ароматичну вітамінну приправу, для покращення апетиту та травлення, додають у вітамінні чаї. Рослина використовується в офіційній та народній медицині, зокрема, для регулювання роботи шлунково-кишкового тракту.

Taraxacum officinale Wigg. aggr. * (Asteraceae), кульбаба лікарська. Трав'янистий полікарпік. Лучний (на луках, пагорбах, схилах, узліссях, галявинах, у лісах, серед чагарників). Як джерело вітамінів, використовують такі частини рослини: листки, бутони, квітки та підземні пагони. Молоді свіжі листки мають гіркуватий смак. Їх вживають у їжу після замочування у холодній солоній воді, додають до овочевих салатів та приправ. Бутони маринують. 3 квіток готують оригінальне кульбабове варення, де навіть при термічній обробці рослина не втрачає корисних властивостей. Підземні пагони сушать, підсмажують, розмелюють та готують напій, який має темний колір, солодкуватий присмак, нагадує каву, покращує апетит і травлення. Як свідчить українська назва, рослина — лікарська, застосовується в офіційній та народній медицині для поліпшення роботи шлунково-кишкового тракту.

Tilia cordata Mill. (Tiliaceae Juss.), липа серцелиста, липа звичайна. Дерево. Лісовий (у лісах, на узліссях). Висушені суцвіття традиційно застосовують для заварювання ароматного липового чаю. Вітамінні напої готують також i 3 молодих листків. Плоди їстівні, мають горіховий смак. Надзвичайно корисним $\mathrm{i}$ смачним $\epsilon$ монофлорний липовий мед. T. cordata - цінна лікарська бактерицидна та потогінна рослина офіційної та народної медицини.

Trifolium pratense L. * (Fabaceae Lindl.), конюшина лучна (рис. 5c). Трав'янистий полікарпік. Лучний (на луках, трав'янистих схилах, узліссях, лісових галявинах, серед чагарників). Надземні пагони конюшини містять значний спектр вітамінів. Збирають та заготовляють верхівки квітучих пагонів. Їх сушать у затіненому місці та використовують для приготування цілющих відварів і настоїв. Рослина має лікарські властивості, застосовується при тривалому кашлі, бронхіальній астмі, гастриті та інших захворюваннях.

Urtica dioica L. * (Urticaceae Juss.), кропива дводомна. Трав’янистий полікарпік. Синантропний (на трав'янистих схилах, луках, узліссях, галявинах, у лісах, поблизу садиб та осель). Це рослина з унікальними властивостями, яка має тривалу історію досліджень використання стебел, листків та коренів, як лікарських засобів та екстрактів, джерела природних вітамінів, енергії, клітковини (Dhouibi et al., 2020). Відростає рано навесні, у березні. У цей час надземна сфера рослини характеризується найвищим вмістом вітамінів і може вживатись у їжу. Молоді пагони кропиви додають до салатів (для інактивації пекучих волосків - ошпарюють окропом), а також до перших і других страв. Для тривалого зберігання кропиву можна заморожувати, засолювати або 
сушити. Препарати кропиви або висушені листки широко застосовують в офіційній та народній медицині внутрішньо, зокрема, як кровоспинний та протизапальний засіб, і зовнішньо, для загоювання ран, покращення росту волосся тощо.
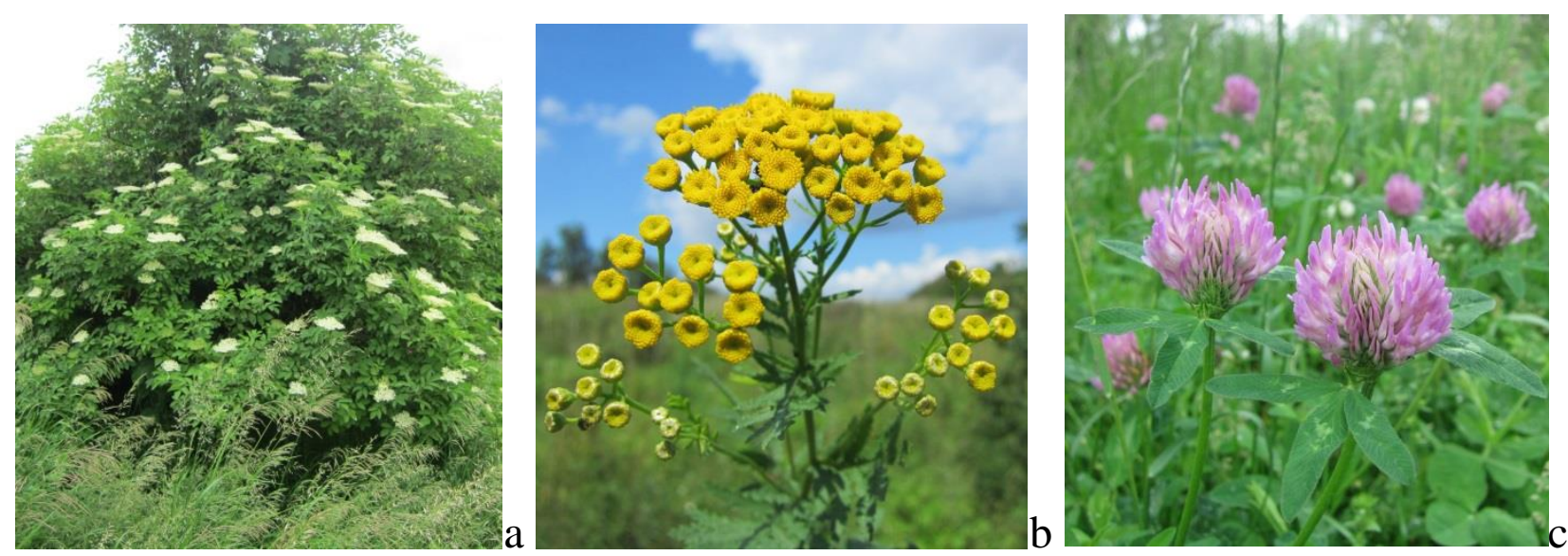

Рисунок 5. a - Sambucus nigra L.; b - Tanacetum vulgare L.; c - Trifolium pratense L. (Фото В. В. Гриценко).

Figure 5. a - Sambucus nigra L.; b - Tanacetum vulgare L.; c - Trifolium pratense L. (Photo by V. V. Gritsenko)

Vaccinium myrtillus L. (Ericaceae Juss.), чорниця звичайна. Кущик. Лісовий (у вологих лісах). Плоди чорниці доцільно вживати свіжими, вони мають бактерицидні та протизапальні властивості, нормалізують обмін речовин і травлення, покращують зір і пам'ять, сприяють виведенню 3 організму шкідливих сполук, містять значну кількість антиоксидантів. Висушені плоди додають до чаїв, компотів. В офіційній та народній медицині використовують плоди й листки: для профілактики та лікування запалень, нормалізації роботи шлунково-кишкового тракту.

Vaccinium vitis-idaea L. (Ericaceae), брусниця звичайна. Кущик. Лісовий (у лісах, на вологих місцях, серед чагарників). Плоди вживають свіжими, або готують з них варення, компоти, додають у напої. Ягоди добре зберігаються у холодильнику упродовж року. Листки виділяють фітонциди, мають антисептичні, протизапальні та дезінфекційні властивості, їх застосовують в офіційній та народній медицині.

Viburnum opulus L. (Caprifoliaceae), калина звичайна, к. червона. Кущ. Лісовий (у лісах, на узліссях, галявинах, вологих луках, серед чагарників). Калину вважають символом України, вона оспівана у народних піснях i легендах. Плоди достигають восени, однак, збирати їх краще після перших заморозків, проморожені плоди мають менш гіркий смак. Їх сушать для чаю або вживають свіжими. Розім'яті свіжі плоди 3 кісточками перемішують з цукром або медом у співвідношенні $1: 1$, вживають, як вітамінний і протизапальний засіб та для зниження тиску, зберігають у холодильнику. В офіційній та народній медицині використовують плоди й кору рослин. Калина - цінна 
рослина 3 різними біологічними ефектами, яка має багатий та різноманітний хімічний склад (Kajszczak et al., 2020).

Як свідчить складений перелік, на Київському плато місцеве населення часто використовує 43 види автохтонних вітаміноносних рослин. У інших регіонах України, відповідно до етноботанічних традицій, пріоритетними можуть бути інші види рослин.

Наведені у переліку 43 види рослин належать до 36 родів та 21 родини. Найбільшу частку в спектрі родин займає Rosaceae, яка містить понад чверть $(26 \%)$ з усіх видів (рис. 6,1$)$. На другому місці - родина Asteraceae, $14 \%$ видів; на третьому - Polygonaceae, $7 \%$ видів (рис. 6, 2-3). Решта, 18 родин, містять по 5-2\% видів (рис. 6, 4-21).

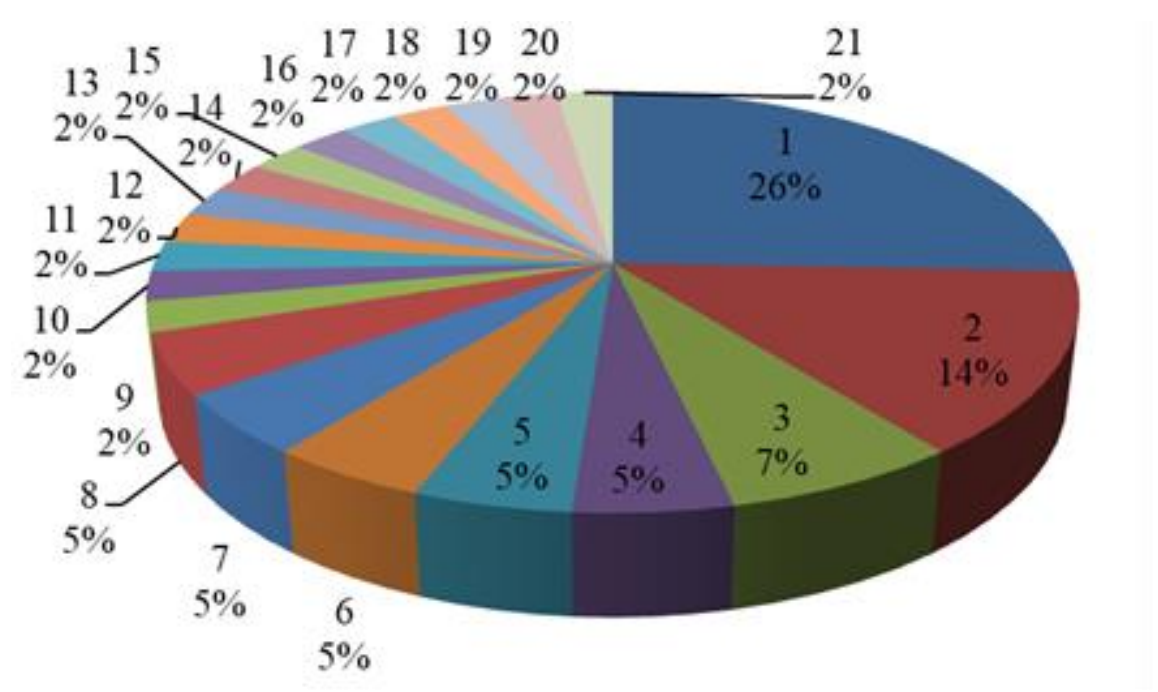

Рисунок 6. Спектр родин автохтонних вітаміноносних видів рослин Київського плато, які часто використовує населення цього регіону: 1 - Rosaceae; 2 Asteraceae; 3 - Polygonaceae; 4-8-Alliaceae, Betulaceae, Caprifoliaceae, Ericaceae, Plantaginaceae; 9-21 - Berberidaceae, Brassicaceae, Caryophyllaceae, Chenopodiaceae, Clusiaceae, Fabaceae, Geraniaceae, Lamiaceae, Pinaceae, Poaceae, Ranunculaceae, Tiliaceae, Urticaceae.

Figure 6. The spectrum of families of autochthonous vitamin-bearing plant species of the Kiev Plateau, which are often used by the population of this region: 1 Rosaceae; 2 - Asteraceae; 3 - Polygonaceae; 4-8 - Alliaceae, Betulaceae, Caprifoliaceae, Ericaceae, Plantaginaceae; 9-21 - Berberidaceae, Brassicaceae, Caryophyllaceae, Chenopodiaceae, Clusiaceae, Fabaceae, Geraniaceae, Lamiaceae, Pinaceae, Poaceae, Ranunculaceae, Tiliaceae, Urticaceae.

У біоморфологічному спектрі частки дерев (16\%) та кущів (18\%) є близькими за об'ємом, сумарно вони складають понад третину (34\%) від загальної кількості видів (рис. 7, 1-2). Участь кущиків є найменшою - 5\% (рис. 7, 3). Переважають трав'янисті рослини - 61\% (рис. 7, 4-5), а саме, трав'янисті полікарпіки - 49\% (рис. 7,4 ). 


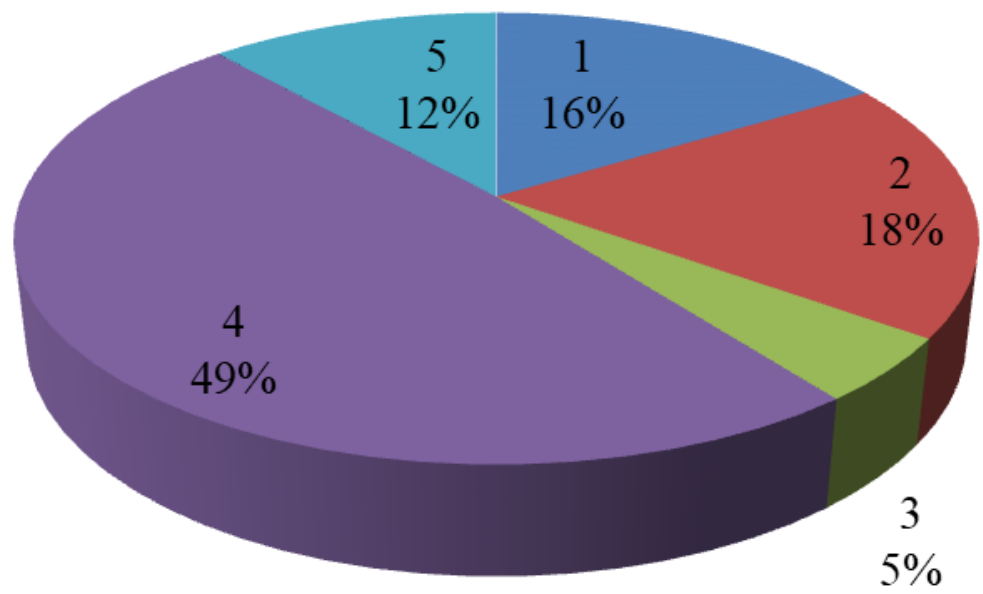

Рисунок 7. Біоморфологічний спектр автохтонних вітаміноносних видів рослин Київського плато, які часто використовує населення цього регіону. Основні життєві форми: 1 - дерева, 2 - кущі, 3 - кущики, 4 - трав'янисті полікарпіки, 5 - трав'янисті монокарпіки

Figure 7. Biomorphological spectrum of autochthonous vitamin-bearing plant species of the Kiev Plateau, which are often used by the population of this region. Basic life forms: 1 - trees, 2 - bushes, 3 - small bushes, 4 - herbaceous polycarpics, 5 - herbaceous monocarpics

На Київському плато автохтонні вітаміноносні рослини трапляються у різних природних фітоценозах: у лісах, на узліссях, галявинах, вологих і сухих луках, лучних степах, пагорбах, трав'янистих i степових схилах, серед чагарників. Кількісне співвідношення видів, приурочених до різних фітоценозів відображає еколого-ценотичний спектр флороценотипів (рис. 8). Лісовий флороценотип (42\%) представлений найбільшою кількістю видів (рис. 8, 1). Вагомою $є$ частка видів лучного флороценотипу (33\%), яка складає третину від загальної кількості (рис. 8, 2). Частка видів степового флороценотипу $(16 \%) \epsilon$ майже вдвічі меншою ніж лучного (рис. 8, 3). Такий розподіл трьох провідних флороценотипів відповідає географічному положенню регіону досліджень та обумовлений етноботанічними традиціями. Участь видів синантропного (7\%) та псамофільного (2\%) флороценотипів - невелика (рис. 8, 4-5).

Традиційно, при практичному застосуванні автохтонних вітаміноносних видів у більшості рослин (46\%) місцеве населення регіону збирає та використовує надземні пагони (рис. 9, 1). Третину від загальної кількості (33\%) становлять рослини, у яких застосовують не лише надземні пагони, а й плоди (рис. 9, 2). 


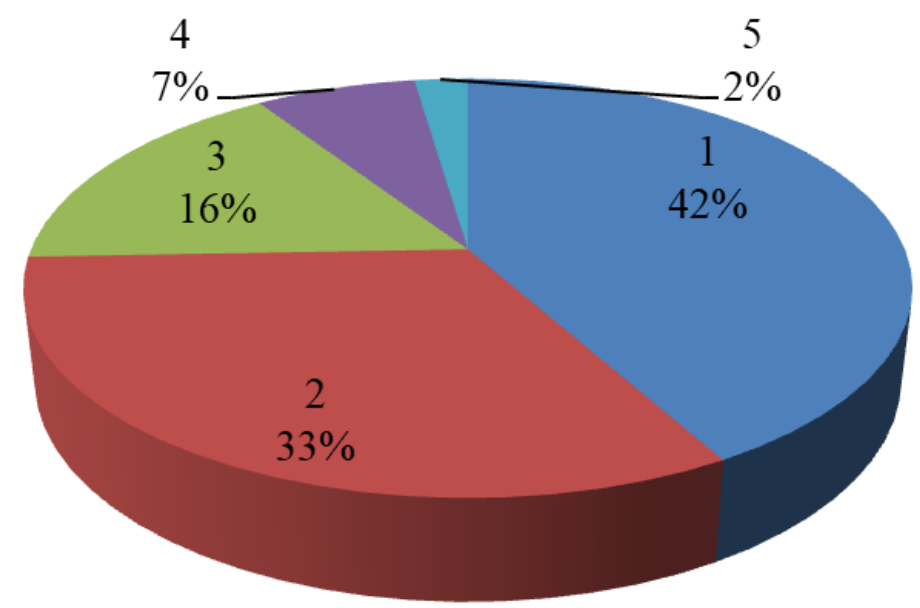

Рисунок 8. Еколого-ценотичний спектр автохтонних вітаміноносних видів рослин Київського плато, які часто використовує населення цього регіону. Флороценотипи: 1 - лісовий, 2 - лучний, 3 - степовий, 4 - синантропний, 5 - псамофільний.

Figure 8. Ecologo-coenotic spectrum of autochthonous vitamin-bearing plant species of the Kiev Plateau, which are often used by the population of this region.

Florocenotypes: 1 - forest, 2 - meadow, 3 - steppe, 4 - synanthropic, 5 psammophilous.

На рослини, у яких використовують надземні та підземні пагони (9\%), лише плоди (7\%) або підземні пагони (5\%) припадають невеликі частки (рис. 9, 3-5). У цілому, найчастіше збирають надземні частини рослин (рис. 9, 1-4), і лише зрідка - підземні пагони (рис. 9, 3, 5).

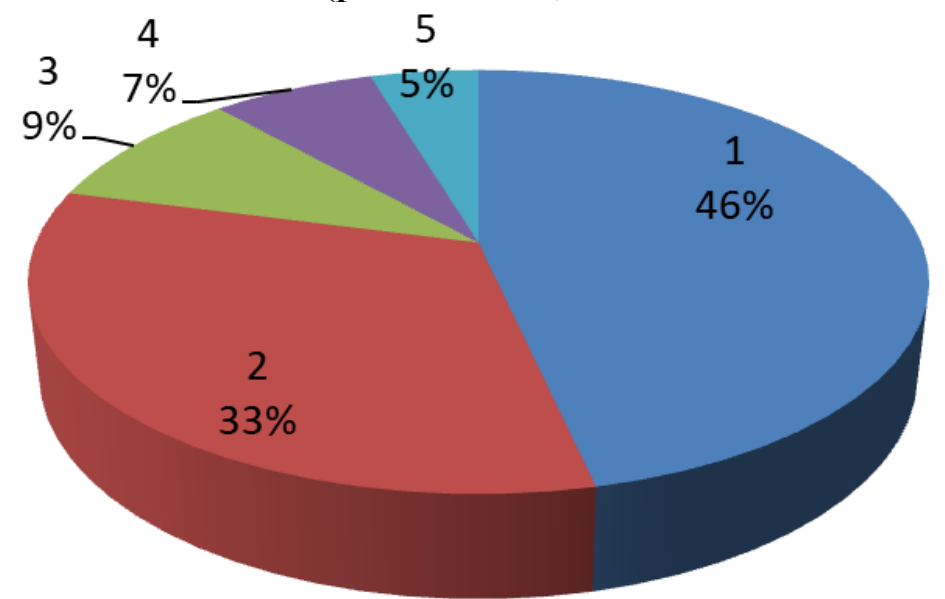

Рисунок 9. Спектр кількості автохтонних вітаміноносних видів рослин Київського плато за пріоритетністю використання певних частин: 1 - надземні пагони, 2 - надземні пагони та плоди, 3 - надземні та підземні пагони, 4 - плоди, 5 - підземні пагони.

Figure 9. The spectrum of the number of autochthonous vitamin-bearing plant species of the Kyiv Plateau by priority of using certain parts: 1 - aboveground shoots, 2 aboveground shoots and fruits, 3 - aboveground and underground shoots,

4 - fruits, 5 - underground shoots. 
Вживання вітаміноносних рослин зміцнюе організм та покращує самопочуття людини. Серед вище охарактеризованих у анотованому переліку рослин, немає видів, які занесені до Червоної книги України (Chervona ..., 2009) та офіційного списку регіонально рідкісних рослин Київської області (Official ..., 2012). Іноді місцеве населення використовує за джерело ранньовесняних вітамінів, посилаючись на необізнаність, раритетні види рослин, зокрема, Allium ursinum L. (цибуля ведмежа, левурда, іноді черемша) та Primula veris L. (первоцвіт весняний). Це недопустимо з фітосозологічної точки зору та потребує покращення природоохоронної просвітницької діяльності. A. ursinum внесений до Червоної книги України (Chervona ..., 2009), природоохоронний статус виду — «неоцінений», його заготівлю та торгівлю заборонено Законом України. Наводимо перелік рослин, які є вітаміноносними, рідко трапляються на Київському плато, а їх використання заборонено, так, як ці види внесені до офіційного списку регіонально рідкісних і зникаючих видів рослин, які потребують охорони у Київській області (Official ..., 2012): Cerasus fruticosa (Pall.) Woronow (вишня степова або кущова), нині визнається як Prunus fruticosa Pall., Crataegus lipskyi Klokov (глід Липського), Crataegus pentagyna Waldst \& Kit. (глід п'ятистовпчиковий), Plantago cornuti Gouan (подорожник Корнута), Plantago salsa Pall. (подорожник солончаковий), Primula veris, Rosa gorenkensis Besser (шипшина Горенка), Rosa jundzilii Besser (шипшина Юджила), Rosa spinosissima L. (шипшина найколючіша).

3 метою проведення стаціонарних наукових досліджень, демонстрації та збереження флористичного різноманіття ex situ у мегаполісах функціонують різні ботанічні установи. Усі наведені у переліку 43 види рослин представлені у м. Київ у НБС, зокрема, більш ніж половина 3 них -28 видів * $(65,1 \%)$ експонуються на ботаніко-географічній ділянці «Степи України» (рис. 1-5).

Висновки/Conclusions. Складено анотований перелік автохтонних вітаміноносних видів рослин Київського плато, які за етноботанічними традиціями часто використовує населення регіону. У переліку охарактеризовані 43 види рослин, які належать до 36 родів та 21 родини. У спектрі родин найбільшу частку займають види Rosaceae (26\%). У біоморфологічному спектрі переважають трав'янисті рослини (61\%), а саме, трав'янисті полікарпіки (49\%). В еколого-ценотичному спектрі найбільшими є частки видів лісового (42\%) та лучного (33\%) флороценотипів. Для практичного застосування населення регіону найчастіше збирає надземні частини рослин, зокрема, надземні пагони $(46 \%)$ або надземні пагони й плоди (33\%). Усі наведені в анотованому переліку види рослин представлені ex situ у НБС. Більш ніж половина 3 них $(65,1 \%)$ експонуються на ботаніко-географічній ділянці «Степи України» НБС.

\section{Список посилань/References}

Aleksandrova, E. V., Shkoda, A. S., Iurchenko, D. N. \& Levich, S. V. (2015). Biokhimicheskie osnovy vitaminologii. Zaporozh'e. 129 s. (in Russian).

Bosse, G. G. (1943). Vitaminonosnye rasteniia SSSR $i$ ikh pishchevoe ispol'zovanie. Moskva: Sovetskaia nauka. 107 s. (in Russian). 
Couto, J., Figueirinha, A., $\quad$ Batista, M. T., $\quad$ Paranhos, A., Nunes, C., Gonçalves, L. M., ... \& Pina, M. E. (2020). Fragaria vesca L. Extract: A Promising Cosmetic Ingredient with Antioxidant Properties. Antioxidants, 9(2), 154. DOI: 10.3390/antiox9020154.

Dhouibi, R., Affes, H., $\quad$ Ben Salem, M., $\quad$ Hammami, S., $\quad$ Sahnoun, Z., Mounir Zeghal, K. \& Ksouda, K. (2020). Screening of pharmacological uses of Urtica dioica and others benefits. Progress in Biophysics and Molecular Biology. Vol. 150. P. 67-77. URL:

https://www.sciencedirect.com/science/article/abs/pii/S0079610719300987.

Dobrochaeva, D. N., $\quad$ Kotov, M. I., $\quad$ Prokudin, Iu. N., Barbarich, A. I., Chopik, V. I., Protopopova, V. V., ... \& Ornst, E. Y. (1999). Opredelitel' vysshikh rasteniy Ukrainy. Izdanie 2-e, stereotipnoe. Kiev: Fitosotsiotsentr. 548 s. (in Russian).

Golubev, V. N. (1972). Printsipy postroeniia i soderzhaniia lineynoy sistemy zhiznennykh form pokrytosemennykh rasteniy. Biulleten' Moskovskogo obshchestva ispytateley prirody. Otdelenie biologii. Vyp. 7, No 6. S. 72-80. (in Russian).

Gritsenko, V. V. (2007). The meadow steppes of the Kyiv plateau: flora, vegetation, population of rare species and protection: dissertation for the degree of candidate of biological sciences. Kyiv. 358 p. (in Ukrainian).

Gritsenko, V. V. (2021). Ethnobotanical aspects of the use of native plants of the Kiev plateau, as sources of natural vitamins. Ethnobotanical Traditions in Agronomy, Pharmacy and Garden Design: Proceedings of the Fourth International Scientific Conference, dedicated to the 30th Anniversary of Independence of Ukraine (Uman, July 5-7, 2021). [Editorial board.: I. Kosenko (Editor-in-Chief) and others]. Uman: Publisher «Sochinskiy M. M.». P. 68-75. (in Ukrainian).

Gusev, N. F., Nemereshina, O. N., Petrova, G. V. \& Filippova, A. V. (2017). Vitaminy. Ekologo-biologicheskie aspekty primeneniia. Orenburg: Orenburgskiy gosudarstvennyy agrarnyy universitet. $240 \mathrm{~s}$. (in Russian).

Kajszczak, D., Zakłos-Szyda, M. \& Podsedek, A. (2020). Viburnum opulus L.A Review of Phytochemistry and Biological Effects. Nutrients, 12(11), 3398. DOI: 10.3390/nu12113398.

Kamelin, R. V. (1973). Florogeneticheskiy analiz estestvennykh flor gornoy Sredney Azii. Leningrad: Nauka. 356 s. (in Russian).

Mendel, M., Chłopecka, M., Latek, U., Karlik, W., Tomczykowa, M., Strawa, J. \& Tomczyk, M. (2020). Evaluation of the effects of Bidens tripartita extracts and their main constituents on intestinal motility - An ex vivo study. Journal of Ethnopharmacology. Vol. 259. DOI: 10.1016/j.jep.2020.112982.

Mosyakin, S. L. \& Fedoronchuk, M. M. (1999). Vascular plants of Ukraine. A nomenclatural checklist. Kiev. 345 p.

Nechitaylo, V. A., Badanina, V. A. \& Gritsenko, V. V. (2005). The cultural plants of Ukraine. Kyiv. 351 p. (in Ukrainian).

Official lists of regional rare plants of administrative territories of Ukraine (reference book). (2012). Compiled by T. L. Andrienko, M. M. Peregrym. Kyiv: Alterpress. 148 p. (in Ukrainian). 
Pehlivan, M., Mohammed, F. S., Sevindik, M. \& Akgul, H. (2018). Antioxidant and oxidant potential of Rosa canina. Eurasian Journal of Forest Science, 6(4). P. 22-25. URL: https://dergipark.org.tr/en/pub/ejejfs/article/475286.

Rahimi-Madiseh, M., Lorigoini, Z, Zamani-gharaghoshi, H. \& Rafieiankopaei, M. (2017). Berberis vulgaris: specifications and traditional uses. Iranian Journal of Basic Medical Sciences, 20(5). P. 569-587. DOI: 10.22038/IJBMS.2017.8690.

Chervona knyha Ukrainy. Roslynnyy svit. (2009). Redaktor Ya. P. Didukh. Kyiv: Hlobalkonsaltinh. 911 s.

Rubtsova, O. L. (2007). Istoriia doslidzhen' vitaminnykh shypshyn v Ukraini. Nauka ta naukoznavstvo, No 4. S. 235-243. (in Ukrainian).

Santos, T. N., Costa, G., Ferreira, J. P., Liberal, J., Francisco, V., Paranhos, A., ... \& Batista, M. T. (2017). Antioxidant, anti-inflammatory, and analgesic activities of Agrimonia eupatoria L. Infusion. Evidence-Based Complementary and Alternative Medicine. DOI: 10.1155/2017/8309894.

Taşc1, B., Kütük, H. \& Koca, İ. (2019). Antioxidant Activity of Allium scorodoprasum L. subsp. rotundum (L.) Stearn. Plant Grown in Turkey. Turkish Journal of Agriculture — Food Science and Technology, 7(10). P. 1561-1567. DOI: 10.24925/turjaf.v7i10.1561-1567.2583.

Zhohlo, F. A., Popovych, V. P., Oliynyk, P. V. \& Shuryn, R. M. (1992). Vitaminonosni likars'ki roslyny. L'viv: Svit. 152 s. (in Ukrainian). 